\title{
Media Papan Pintar Pancasila sebagai Upaya Peningkatan Hasil Belajar Siswa Kelas II SD Negeri 2 Payaman Nganjuk
}

\author{
Diterima: \\ 4 Januari 2021 \\ Revisi: \\ 26 Januari 2021 \\ Terbit: \\ 1 Februari 2021
}

\author{
Indah Pramitasari \\ SDN 2 Payaman, \\ Nganjuk, Indonesia \\ E-mail: indahmeetha@yahoo.com
}

\begin{abstract}
Abstrak - Salah satu pendidikan yang berperan sebagai pembentuk karakter bangsa yaitu Pendidikan Kewarganegaraan. Materi PPKn umumnya disajikan sangat teoritis, abstrak dan sulit dipahami oleh siswa. Selain itu, kurangnya keterampilan guru mengembangkan model dan media pembelajaran PPKn menyebabkan siswa kurang terlibat dalam proses pembelajaran, sehingga berdampak pada hasil belajar yang cukup rendah. Alternatif media pembelajaran yang dapat digunakan pada muatan PPKn ialah Papan Pintar Pancasila, dimana siswa dapat bermain dan mencocokkan gambar sesuai sila secara individu maupun kelompok. Tujuan dalam penelitian ini untuk meningkatkan hasil belajar PPKn melalui media Papan Pintar Pancasila pada siswa kelas II di SDN 2 Payaman, Nganjuk. Rancangan penelitian yang digunakan adalah penelitian tindakan kelas yang terdiri dari 2 siklus. Subjek penelitian ini adalah siswa kelas II SDN 2 Payaman Nganjuk yang berjumlah 27 siswa. Data penelitian diperoleh melalui observasi, tes, dan catatan lapangan. Data observasi kegiatan pembelajaran dianalisis dalam bentuk persentase dan nilai rata-rata kegiatan pembelajaran. Data tes hasil belajar siswa dianalisis dengan menjumlahkan nilai setiap aspek yang dinilai dan berdasarkan persentase ketuntasan belajar klasikal. Data catatan lapangan yang berisi berbagai kendala dianalisis kemudian dicari solusinya. Hasil penelitian menunjukkan bahwa hasil belajar siswa dalam pembelajaran mengalami peningkatan. Pada siklus I hasil belajar siswa mencapai 72,88\% dan pada siklus II hasil belajar siswa mencapai 80,68\%. Kesimpulan yang dapat diambil dari penelitian ini adalah penggunaan Media Papan Pancasila dapat meningkatkan hasil belajar siswa pada pembelajaran PPKn di kelas II SDN 2 Payaman Nganjuk.
\end{abstract}

Kata Kunci- hasil belajar, media Papan Pintar Pancasila, PPKn

\begin{abstract}
One of the educations that play a role in shaping the nation's character is Citizenship Education. The material for low grade Civics is generally very theoretical, abstract and difficult for students to understand. In addition, the lack of teacher skills in developing Civics learning models and media causes students to be less involved in the learning process, so that the impact on learning outcomes is quite low. Alternative learning media that can be used for low grade Civics is the Pancasila Smart Board, where students can play and match pictures according to the precepts individually or in groups. The purpose of this study is to improve learning outcomes of Civics through the Pancasila Smart Board media for second grade students at SDN 2 Payaman, Nganjuk. The research design used was classroom action research which consisted of 2 cycles. The subjects of this study were the second grade students of SDN 2 Payaman Nganjuk, totaling 27 students. Research data obtained through observation, tests, and field notes. Observation data of learning activities were analyzed in the form of percentages and the average value of learning activities. Data on student learning outcomes were analyzed by adding up the scores for each aspect assessed and based on the percentage of classical learning completeness. Field note data containing various obstacles were analyzed and then looked for solutions. The results showed that student learning outcomes in learning have increased. In the first cycle student learning outcomes reached $72.88 \%$ and in the second cycle student learning outcomes reached $80.68 \%$. The conclusion that can be drawn from this research is the use of Pancasila Board Media can improve student learning outcomes in Civics learning in class II SDN 2 Payaman Nganjuk.
\end{abstract}

Keywords - learning outcomes, Pancasila Smart Board media, PPKn 


\section{PENDAHULUAN}

Salah satu pendidikan yang berperan sebagai pembentuk karakter bangsa yaitu Pendidikan Kewarganegaraan. Pendidikan Kewarganegaraan merupakan semangat perjuangan bangsa yang merupakan kekuatan mental spritual telah melahirkan kekuatan yang luar biasa dalam masa perjuangan fisik, sedangkan dalam mengahadapi globalisasi untuk mengisi kemerdekaan memerlukan perjuangan non fisik sesuai dengan bidang profesi masing-masing (Sumarsono 2001). Perjuangan dilandasi oleh nilai-nilai perjuangan bangsa sehingga tetap memiliki wawasan dan kesadaran kenegaraan dan kebangsaan, sikap perilaku cinta tanah air dan mengutamakan persatuan serta kesatuan bangsa dalam rangka bela negara demi tetap utuh dengan tegak berdirinya Negara Kesatuan Republik Indonesia (SA 2018).

Karakteristik siswa SD menurut Piaget berada pada tahap operasional konkret, dimana siswa mudah menerima materi yang abstrak dan teoritis melalui benda-benda nyata. Senada dengan pernyataan tersebut, Sugiyanto (2015) memaparkan bahwa siswa SD umumnya mempunyai karakteristik senang bermain, senang bergerak, senang bekerja dalam kelompok dan senang merasakan atau memperagakan sesuatu secara langsung. Oleh karena itu, perlu adanya suatu bentuk pembaharuan dalam proses pembelajaran agar lebih berpusat pada siswa dengan melibatkan siswa secara aktif dalam proses pembelajaran melalui model atau media pembelajaran yang sesuai.

Salah satu media pembelajaran yang dapat digunakan di kelas rendah adalah media papan pintar pancasila. Alat peraga edukatif yaang saya buat yaitu "Papan Pintar Pancasila" yang digunakan untuk kelas II SD/MI. Tujuan pembuatan alat peraga ini adalah sebagai media pembelajaran yang dapat memudahkan siswa dalam memahami arti dari setiap sila dalam pancasila. Kelebihan dari Alat peraga ini adalah dengan tampilan yang warna warni dapat meningkatkan minat siswa dalam mempelajari materi yang disampaikan. Dengan mencocokkan sila dan contoh sikap tanpa disadari mereka bermain sambil belajar. Sehingga materi akan lebih mudah dipahami oleh siswa. Penyajian dengan adanya contoh sikap setiap sila dapat mengajarkan kepada siswa sejak dini mengenai hidup berlandaskan pancasilasebagai sikap warga negara yang baik. Adapun kekurangan dari Alat peraga ini adalah tulisan keterangan pada contoh sikap yang terlalu kecil membuat siswa yang duduk agak jauh dari Alat peraga ini akan susah dalam melihat tulisan tersebut. Selain itu, bahan Alat peraga yang sebagian terbuat dari kardus membuatnya sangat mudah rusak (sobek). Berikut merupakan cara penggunaan Alat peraga "Papan Pintar Pancasila": 1) Dipertemuan sebelumnya guru sudah mengenalkan apa pancasola dan arti dari setiaap sila. 2) Guru menghimbau agar murid berhitung 1-5, dan siswa berkumpul sesuai angka yang diperoleh, 3) Setiap ketua memilih 2 orang sebagai perwakilan PTK: Jurnal Tindakan Kelas | Hal:68-76 
PTK, Vol.2 No.1 2021

ISSN: 2747-1977 (Print) / 2747-1969 (Online)

DOI: https://doi.org/10.53624/ptk.v2i1.47

untuk maju kedepanuntuk mencocokkan arti dan contoh sikap sesuai yang diisyaratkan oleh kelompok masing-masing. 4) Setiap kelompok diberi waktu 5 menit untuk menyusun arti dan contoh sikap, setelah itu teman dari kelompok lain berasama-sama dengan guru menilai apakah hasilnya sesuai atau tidak. Dengan alat peraga ini diharapkan guru lebih mudah dalam menyampaikan materi kepada siswa dan siswa juga mudah menangkap materi yang telah disampaikan.

Adapun tujuan penelitian dari pemaparan latar belakang permasalahan tersebut adalah untuk meningkatkan hasil belajar PPKn melalui media papan pintar pancasila pada siswa kelas II di SD Negeri 2 Payaman. Manfaat yang dapat dikontribusikan melalui penelitian tindakan kelas ini ialah sebagai berikut: 1) Bagi guru, hasil penelitian ini dapat dijadikan bahan refleksi terhadap implementasi proses pembelajaran PPKn yang bersifat teoritis, juga sebagai masukan untuk meningkatkan proses pembelajaran di kelas sehingga selanjutnya dapat mempertahankan atau meningkatkannya. 2) Bagi siswa, dapat menjadi sarana untuk meningkatkan hasil belajar dan mengembangkan kepribadian sebagai pribadi yang utuh. 3) Bagi peneliti lain, dapat digunakan sebagai acuan dalam bidang penelitian sejenis secara lebih mendetail dan mendalam.

\section{METODE}

Setting penelitian dilakukan di kelas II SD Negeri 2 Payaman. Subjek penelitian ini ialah siswa dan guru kelas II SD Negeri 2 Payaman dengan jumlah siswa 27 orang, terdiri dari 16 siswa laki-laki dan 11 siswa perempuan. Jenis penelitian yang dilakukan ialah Penelitian Tindakan Kelas ialah suatu pencermatan terhadap kegiatan belajar berupa sebuah tindakan yang disengaja dimunculkan dan terjadi di dalam kelas secara bersama (Arikunto 2008). Penelitian ini berupaya untuk meningkatkan hasil belajar PPKn pada siswa kelas II dengan menggunakan media papan pintar pancasila di SD Negeri 2 Payaman.

Metode dan alat pengumpul data yang diperlukan dalam penelitian tindakan kelas ini berupa observasi, dokumentasi dan metode tes (terdiri dari pre-test dan post-test). Teknik analisis data dalam penelitian ini dengan merefleksikan hasil observasi dari penggunaan media papan pintar pancasila dalam meningkatkan hasil belajar siswa dan tes untuk mengetahui hasil belajar siswa selama proses tindakan berlangsung. Analisis data observasi secara kualitatif dan analisis hasil belajar secara kuantitatif digunakan dalam penelitian tindakan kelas ini (Slamet 2020). 
Hasil perhitungan dikonsultasikan dengan Kriteria Ketuntasan Minimal (KKM) muatan PPKn Kelas II SDN 2 Payaman, apabila nilai hasil belajar $\geq 75$ maka tuntas dan $<75$ tidak tuntas. Kemudian menghitung persentase ketuntasan belajar klasikal (Aqib et al. 2009).

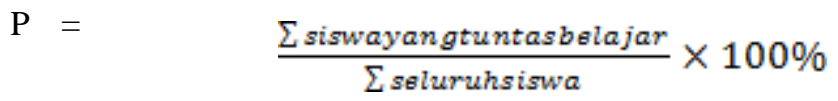

$P=\quad$ Persentase siswa yang tuntas

Hasil perhitungan kemudian dikonsultasikan dengan tabel kriteria penilaian kualitatif yang dikelompokkan dalam lima kategori berikut.

Tabel 1. Kriteria Tingkat Keberhasilan Belajar Siswa dalam \%

\begin{tabular}{cc}
\hline Tingkat keberhasilan & Arti \\
\hline$>80 \%$ & Sangat tinggi \\
\hline $76-79 \%$ & Tinggi \\
\hline $70-75 \%$ & Sedang \\
\hline $66-69 \%$ & Rendah \\
\hline$<60 \%$ & Sangat rendah \\
\hline
\end{tabular}

Berdasarkan uraian di atas, peneliti menentukan bahwa pembelajaran PPKn menggunakan media Puzzle Pancasila berhasil apabila siswa memiliki ketuntasan belajar individu mencapai nilai $\mathrm{KKM} \geq 75$ dengan ketuntasan belajar secara klasikal sebesar $\geq 80 \%$ dari keseluruhan siswa kelas II SDN 2 Payaman.

\section{HASIL DAN PEMBAHASAN}

Penelitian tindakan kelas ini dilakukan di kelas II dengan subjek penelitian berjumlah 27 siswa. Dalam penelitian ini proses belajar mengajar dilaksanakan dengan menggunakan media papan pintar pancasila yang dilakukan dalam 3 siklus, masing-masing siklus terdiri dari 1 pertemuan. Berdasarkan pemaparan permasalahan diatas, peneliti melakukan penelitian tindakan kelas dengan menerapkan media papan pintar pancasila untuk meningkatkan hasil belajarPPKn pada siswa kelas II SDN 2 Payaman.

\section{A. Hasil Observasi Pra Siklus}

Berdasarkan observasi awal (pra siklus) pada siswa kelas II di SDN 2 Payaman diperoleh permasalahan pada pembelajaran PPKn. Hambatan dari permasalahan tersebut disebabkan dari faktor guru dan siswa. Guru belum sepenuhnya menerapkan pembelajaran berpusat pada siswa sehingga siswa tidak dapat mengembangkan kemampuan berpikir kritis sesuai dengan konten materi ajar. Selain itu, guru belum menggunakan media pembelajaran PTK: Jurnal Tindakan Kelas | Hal:68-76 
PTK, Vol.2 No.1 2021

ISSN: 2747-1977 (Print) / 2747-1969 (Online)

DOI: https://doi.org/10.53624/ptk.v2i1.47

sebagai penunjang belajar siswa. Akibatnya siswa merasa bosan dan cenderung melakukan aktivitasnya sendiri. Hal itu menyebabkan materi yang disampaikan oleh guru masih terkesan teoritis, abstrak dan kurang dipahami oleh siswa, sehingga berdampak pada hasil belajar siswa yang rendah. Data hasil belajar siswa pra siklus tersaji dalam tabel berikut.

Tabel 2. Data hasil belajar klasikal pra siklus

\begin{tabular}{clc}
\hline No & \multicolumn{1}{c}{ Pencapaian } & Hasil \\
\hline 1. & Nilai terendah & 55 \\
\hline 2. & Nilai tertinggi & 100 \\
\hline 3. & KKM & 75 \\
\hline 4. & Rata-rata & 65 \\
\hline 5. & Jumlah siswa tuntas & 10 \\
\hline 6. & Jumlah siswa tidak tuntas & 17 \\
\hline 7. & Persentase ketuntasan & $37,03 \%$ \\
\hline 8. & Persentase ketidaktuntasan & $62,96 \%$ \\
\hline
\end{tabular}

Dari tabel 2 dapat diketahui bahwa nilai tertinggi 100 dan nilai terendah 55. Rata- rata nilai hasil belajar pra siklus siswa adalah 65. Hanya 10 siswa yang memperoleh nilai diatas KKM dan sisanya sebanyak 17 siswa memperoleh nilai di bawah KKM yang telah ditetapkan yaitu 75. Persentase ketuntasan belajar siswa pra siklus dapat dilihat dalam gambar 1.

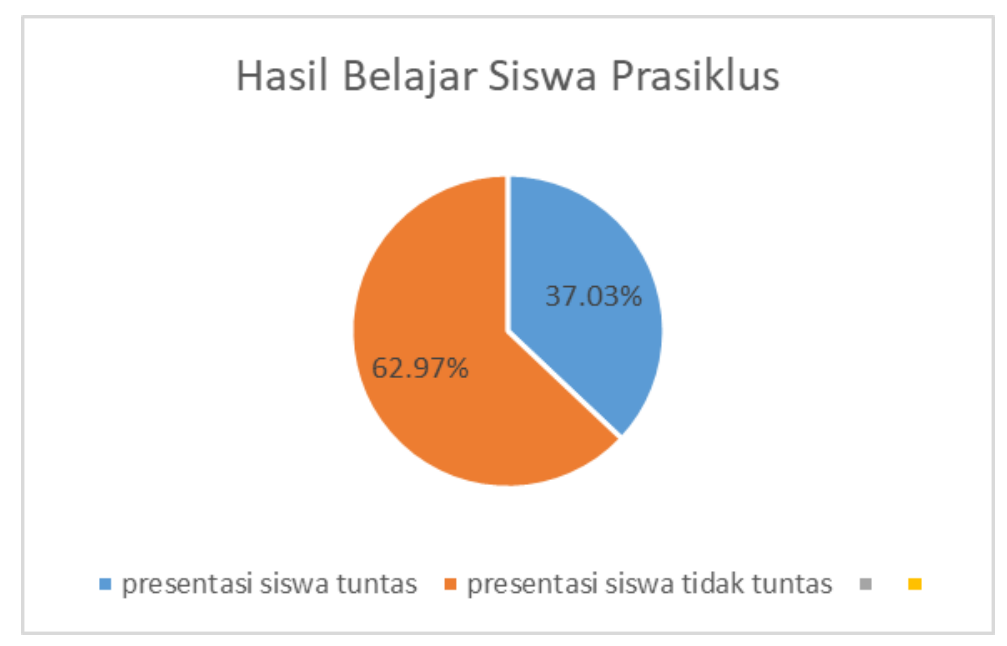

Gambar 1. Hasil Belajar Siswa Pra Siklus

Dari hasil nilai pra siklus tersebut maka diketahui bahwa nilai pencapaian ketuntasan hasil belajar siswa dalam pembelajaran PPKn masih kurang optimal, dimana sebagian besar siswa belum mencapai kriteria ketuntasan minimal (KKM) yang telah ditetapkan sekolah. Data hasil belajar siswa menunjukkan bahwa siswa yang mencapai KKM hanya 10 siswa $(37,03 \%)$ dari 27 siswa. Sedangkan 17 siswa $(62,97 \%)$ yang lain belum mencapai KKM yang telah ditetapkan yaitu 75 . 


\section{B. Siklus 1}

Perencanaan pada siklus I meliputi a) menelaah materi PPKn dan menetapkan indikator pencapaian kompetensi, b) menyiapkan materi dan sumber belajar simbol-simbol Pancasila, c) menyiapkan media papan pintar pancasila, d) menyiapkan lembar kerja peserta didik dan soal evaluasi, e) menyiapkan instrumen pengumpulan data.

Pelaksanaan tindakan pada siklus I meliputi kegiatan awal dimulai dengan salam, menanyakan kabar siswa, melakukan presensi, apersepsi dan motivasi serta kegiatan literasi. Pada kegiatan inti, siswa diminta untuk berkelompok. Kemudian guru menampilkan gambar burung garuda pancasila di power point, siswa diminta untuk mengamati secara seksama. Guru mengajak siswa menyanyikan lagu Garuda Pancasila. Setelah itu, guru memberikan LKPD kepada siswa untuk melakukan tugas kelompok yakni bermain memasangkan potongan gambar simbol sila Pancasila dan penerapan sila pancasila. Pembelajaran diakhiri dengan melakukan refleksi, membuat kesimpulan, mengerjakan tes evaluasi, memberikan motivasi verbal kepada siswa, serta salam penutup.

Observasi dilakukan selama proses pembelajaran berlangsung. Proses belajar mengajar pada siklus I kurang kondusif. Beberapa siswa belum menunjukkan sikap berdoa dengan baik, terlihat ada yang mengganggu temannya ketika berdoa, mengobrol dan belum mampu kerjasama dengan kelompok. Hasil belajar Kompetensi Sikap Spiritual. Dari data hasil belajar Kompetensi Pengetahuan menunjukkan bahwa 74\% atau sebanyak 20 dari 27 siswa mengalami ketuntasan belajar dengan $\mathrm{KKM} \geq 75$ sedangkan $26 \%$ atau 7 siswa lainnya belum tuntas dalam belajar. Ketuntasan belajar klasikal pada Kompetensi Keterampilan (KI-4) sebesar $74 \%$ yaitu 20 siswa tuntas dan persentase ketidaktuntasan $26 \%$ yaitu 7 siswa tidak tuntas.

Hasil refleksi menunjukkan bahwa muatan pelajaran PPKn menggunakan media papan pintar pancasila pada siswa kelas II SDN 2 Payaman perlu untuk dilanjutkan ke siklus II karena indikator keberhasilan yang diharapkan belum terpenuhi yaitu $80 \%$ dan masih ada kelemahan yang harus diperbaiki.

\section{Siklus II}

Perencanaan pada siklus II meliputi a) membuat rangkuman perbaikan dari siklus I, b) menelaah materi PPKn dan menetapkan indikator pencapaian kompetensi, c) menyiapkan materi dan sumber belajar simbol-simbol Pancasila, d) menyiapkan media papan pintar pancasila, e) menyiapkan lembar kerja peserta didik dan soal evaluasi, f) menyiapkan instrumen pengumpulan data. 
PTK, Vol.2 No.1 2021

ISSN: 2747-1977 (Print) / 2747-1969 (Online)

DOI: https://doi.org/10.53624/ptk.v2i1.47

Pelaksanaan tindakan pada siklus II meliputi kegiatan awal dimulai dengan salam, menanyakan kabar siswa, melakukan presensi, apersepsi dan motivasi serta kegiatan literasi. Kegiatan inti dimulai dengan kembali menyanyikan lagu Garuda Pancasila agar siswa bersemangat. Kemudian, guru menampilkan poster pancasila, serta mengulas bacaan Pancasila yang biasa di lafalkan pada hari Senin ketika upacara bendera. Siswa mengamati simbol-simbol sila Pancasila yang tertera di layar LCD, kemudian seluruh siswa secara bersamaan diminta untuk menghafalkan tata letak simbol tersebut. Setelah itu, guru memberikan LKPD kepada siswa untuk memasangkan potongan gambar dan contoh penerapan sila pancasila. Pembelajaran diakhiri dengan melakukan refleksi, membuat kesimpulan, mengerjakan tes evaluasi, memberikan motivasi verbal kepada siswa, serta salam penutup.

Observasi dilakukan selama proses pembelajaran berlangsung. Proses belajar mengajar pada siklus II cukup kondusif. Sebagian besar siswa sudah menunjukkan sikap berdoa dengan baik, tidak ada yang mengobrol dan mampu kerjasama dengan kelompok. Dari data hasil belajar Kompetensi Pengetahuan menunjukkan bahwa 100\% atau sebanyak 27 dari 27 siswa mengalami ketuntasan belajar dengan $\mathrm{KKM} \geq 75$

Hasil refleksi menunjukkan bahwa terjadi peningkatan hasil belajar pada muatan pelajaran PPKn menggunakan papan pintar pancasila, karena indikator keberhasilan yang diharapkan sudah terpenuhi yaitu $80 \%$.

\section{Pembahasan}

Berdasarkan data penemuan penelitian di lapangan, pada pra siklus, siklus I, dan II Secara terperinci pembahasan hasil belajar akan dijabarkan sebagai berikut.

Kompetensi pengetahuan diukur dengan menggunakan soal evaluasi yang dikerjakan oleh siswa secara individu diakhir pembelajaran. Adapun rekapitulasi ketuntasan klasikal hasil belajar Kompetensi Pengetahuan (KI-3) disajikan kedalam tabel berikut.

Tabel 3. Rekapitulasi Ketuntasan Klasikal Hasil Belajar Kompetensi Pengetahuan(KI-3) Pra Siklus, Siklus I dan II

\begin{tabular}{llll}
\hline Kriteria & Pra siklus & Siklus I & Siklus II \\
\hline Ketuntasan Klasikal & $37,03 \%$ & $74,00 \%$ & $100 \%$ \\
\hline Jumlah Siswa Tuntas & 10 & 20 & 27 \\
\hline Jumlah Siswa Tidak Tuntas & 17 & 7 & 0 \\
\hline Tingkat Keberhasilan & Sedang & Sedang & Sangat Tinggi \\
\hline
\end{tabular}




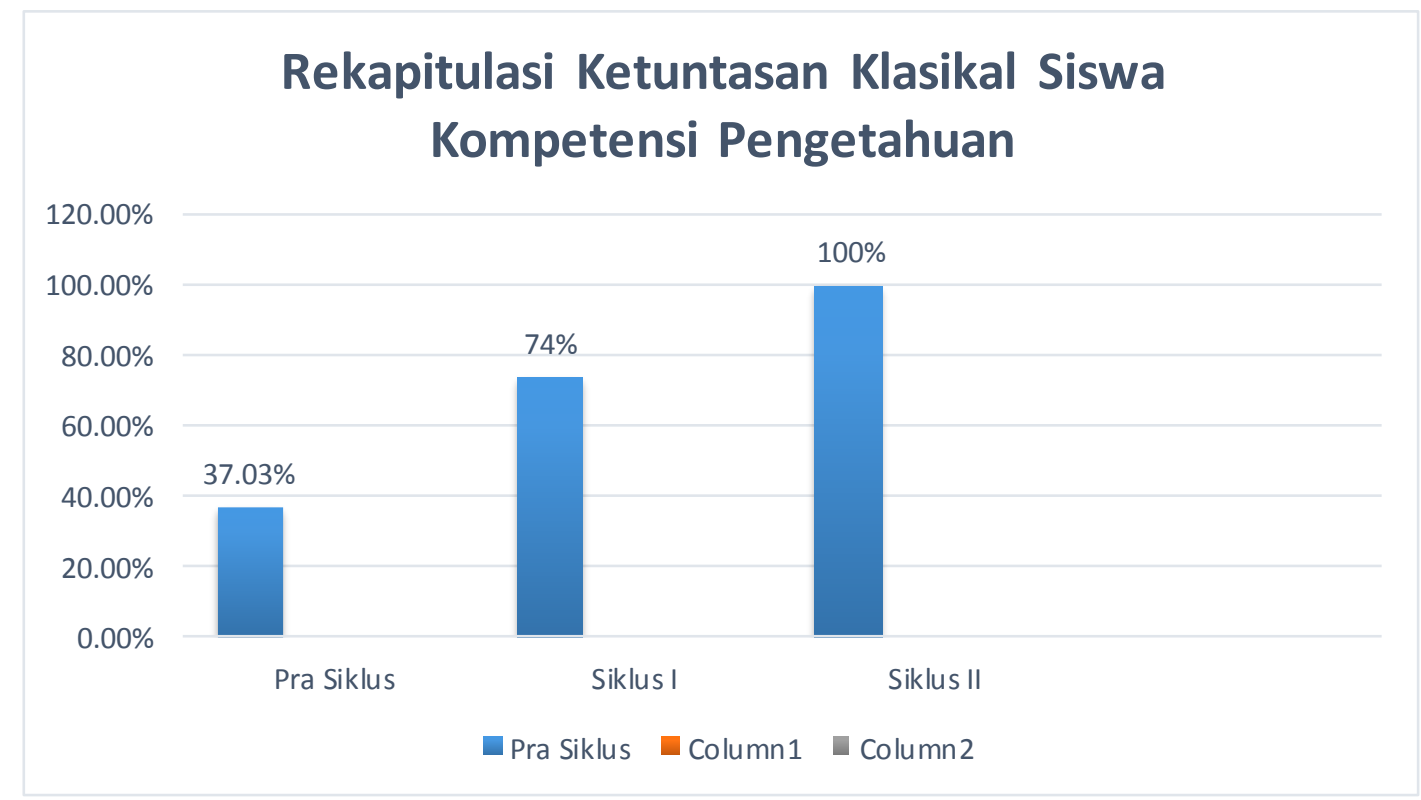

Gambar 2. Rekapitulasi Ketuntasan Klasikal Hasil Belajar Kompetensi

Pengetahuan Pra Siklus, Siklus I, dan II

Berdasarkan tabel 3 dan gambar 2, persentase ketuntasan klasikal hasil belajar kompetensi pengetahuan siswa pada setiap siklus menunjukkan adanya peningkatan. Pada Pra Siklus persentase ketuntasan klasikal siswa yaitu 37,03\% dan meningkat menjadi 74,00\% pada siklus I, kemudian kembali meningkat pada siklus II menjadi 100\%. Data di atas menunjukkan bahwa perolehan kompetensi pengetahuan pada pra siklus dan siklus I belum memenuhi indikator keberhasilan yang ditetapkan karena masih berada dibawah $80 \%$. Sementara itu, ketuntasan klasikal pada siklus II sudah memenuhi indikator keberhasilan yang telah ditetapkan karena capaian ketuntasan klasikal diatas $80 \%$.

Berdasarkan paparan hasil belajar siswa pada kompetensi pengetahuan menunjukkan bahwa terjadi peningkatan pada setiap siklus. Hal tersebut terjadi karena aktivitas siswa meningkat seiring dengan keterampilan guru yang meningkat, karena hasil belajar merupakan hasil timbal balik dari aktivitas siswa pada saat pembelajaran dan keterampilan guru ketika mengajar. Peningkatan tersebut juga tidak lepas dari penggunaan media papan pintar pancasila pada materi PPKn dalam penelitian.

Berdasarkan paparan data hasil belajar PPKn menggunakan media papan pintar pancasila pada siswa kelas II SDN 2 Payaman, menunjukkan peningkatan pada setiap siklusnya. Adanya peningkatan ini tak terlepas dari penggunaan media papan pintar pancasila yang mengubah siswa yang awalnya pasif menjadi sangat aktif, semakin memahami materi yang diajarkan, mampu bekerjasama dengan kelompok, semakin cekatan, bertanggungjawab dan PTK: Jurnal Tindakan Kelas | Hal:68-76 
PTK, Vol.2 No.1 2021

ISSN: 2747-1977 (Print) / 2747-1969 (Online)

DOI: https://doi.org/10.53624/ptk.v2i1.47

selalu termotivasi untuk belajar. Pengaruh positif ini sesuai dengan manfaat media menempel gambar dan simbol pancasila di papan pintar pancasila bagi siswa diantaranya: 1) meningkatkan keterampilan kognitif, 2) meningkatkan keterampilan motorik halus, 3) meningkatkan keterampilan sosial. Sejalan dengan pernyataan tersebut, Rosdijati (2012) menyatakan bahwa media puzzle memiliki keunggulan, diantaranya 1) melatih psikomotorik, 2) melatih daya ingat siswa, 3) suasana kelas menjadi bergairah, 4) adanya interaksi antar siswa, 5) siswa termotivasi melakukan kegiatan, 6) siswa mampu bekerjasama dalam kelompok.

Dengan demikian, penggunaan media papan pintar pancasila dalam pembelajaran dapat membantu siswa dalam memahami dan meningkatkan perhatian siswa terhadap isi materi yang diajarkan, sehingga dapat meningkatkan hasil belajar. Sama halnya dengan penggunaan media papan pintar pancasila yang terbukti mampu meningkatkan hasil belajar PPKn pada siswa kelas II SDN 2 Payaman.

\section{KESIMPULAN}

Berdasarkan data penelitian menunjukkan peningkatan hasil belajar sebagai berikut. Hasil belajar kompetensi pengetahuan Pra siklus memperoleh persentase ketuntasan klasikal 37,03\%, meningkat pada siklus I sebesar 74,00\%, dan meningkat pada siklus II sebesar 100\%. Perolehan skor hasil belajar mengalami peningkatan pada ketiga siklus dan memenuhi indikator keberhasilan sebesar $100 \%$ pada siklus ke II. Dengan demikian dapat disimpulkan bahwa penggunaan media papan pintar pancasila dapat meningkatkan hasil belajar siswa kelas II SDN 2

\section{DAFTAR PUSTAKA}

Aqib, Zainal et al. 2009. Penelitian Tindakan Kelas untuk Guru SD, SLB dan TK. Bandung: Yrama Widya.

Arikunto, Suharsimi. 2008. Penelitian Tindakan Kelas (PTK). Jakarta: Bumi Aksara.

Karanggebang Kecamatan Jetis." Jurnal Ilmiah Pengembangan Pendidikan (JIPP) 7(1):68-76. Sumarsono, Susarso. 2001. Pendidikan Kewarganegaraan. Gramedia Pustaka Utama.

Rosdijati, Nani. 2012. Panduan Pakem IPS SD. Jakarta: Erlangga.

SA, Utami Dewi. 2018. "Penguatan Nilai-Nilai Kebangsaan Melalui Pembelajaran PKn Di Tengah Arus Globalisasi." El-Hamra 3(3):23-28.

Slamet, Slamet. 2020. "Peningkatan Hasil Belajar Pendidikan Kewarganegaraan Tentang Proses

Perumusan Pancasila Melalui Penerapan Metode Belajar Pintar Siswa Kelas VI SDN 2

Sugiyanto. 2015. Model-model Pembelajaran Inovatif. Jakarta: Yuma Pustaka. 